\title{
Antifungal Activity and Genetic Diversity of Selected Endophytic Fluorescent Pseudomonads
}

\author{
Fathalla Alaa M. ${ }^{1}$; Samy A. M. Abd El-Azeem ${ }^{2}$; Metwaly A. Baraka ${ }^{1}$ and Elshahat M. $\operatorname{Ramadan}^{3}$ \\ ${ }^{1}$ Department of Agricultural Botany, Faculty of Agriculture, Suez Canal University, Ismailia, Egypt \\ ${ }^{2}$ Department of Soil and Water, Faculty of Agriculture, Suez Canal University, Ismailia, Egypt \\ ${ }^{3}$ Department of Agricultural Microbiology, Faculty of Agriculture, Ain-Shams University, Cairo, Egypt
}

\section{Received: $1 / 9 / 2015$}

\begin{abstract}
Fluorescent Pseudomonads have been effectively utilized for controlling major fungal plant diseases because of their antifungal metabolites. In this study, thirty-four bacterial isolates were isolated from root samples of different crops and screened as potential biological control agents against Rhizoctoniasolani AG 2-2, Pythium arrhenomanes and Fusarium solani. On the basis of dual culture assays, twenty isolates were selected for phenotypic characterization, identification and plant growth promoting traits; four isolates were selected for greenhouse studies. The selected Pseudomonas strains were characterized by PCR methods using rpob primer. Eight showed the ability to produce indole acetic acid (IAA) while 12 isolates have no IAA produced, thirteen isolates could solubilize inorganic phosphate and six strains produced hydrogen cyanide. Tested Pseudomonas strains had positive response on bean growth and health. Obtained results indicated that the tested antagonistic fluorescent pseudomonads reduced disease severity in beans and disease development under greenhouse pot experiment. However, further study is needed to apply to these results under field conditions.
\end{abstract}

Keywords: Biological control, antagonists, identification, IAA, inorganic phosphate, solubilizers.

\section{INTRODUCTION}

Plant growth promoting rhizobacteria (PGPR) are known to rapidly colonize the rhizosphere and suppress soilborne pathogens at the root surface (Rangarajan et al., 2003). The PGPR can also be beneficial to the plant by stimulating growth (Bloemberg and Lugtenberg, 2001; Moeinzadeh et al., 2010). Among these organisms, fluorescent pseudomonads are considered to be the most promising group of PGPR involved in the biocontrol of plant diseases (Gardner et al., 1984; Moeinzadeh et al., 2010).Fluorescent Pseudomonads can be produce supplementary metabolites such as antibiotics (Keel, 1992), phytohormones (Keel, 1992), volatile compound hydrogen cyanide (HCN) (Defago and Haas, 1990), in addition to produce siderophores (Neilands, 1995). Plant growth-promoting ability of these bacteria is as a result of manufacturing of IAA (Patten and Glick, 2002). In the present study, the isolates were identified according to molecular characterizations by rpob primer. The possible growthpromoting and biocontrol potential of the strains have been investigated by determining the secondary metabolites, viz IAA, solubilization of inorganic phosphate and HCN production. Bean growth response to inoculation with the selected four antagonistic Pseudomonas strains was also evaluated as well as root colonization and severity disease.

\section{MATERIALS AND METHODS}

Isolation of endophytic fluorescent pseudomonads

Root samples of different crops (wheat, bean, clover, tomato and Mango) were collected from the experimental farm, Faculty of Agriculture, Suez Canal University, Ismailia. Roots were removed from the collected plants, thoroughly washed under a running tap water for $5 \mathrm{~min}$ to remove adhering soil particles and cut into $2-3 \mathrm{~cm}$ pieces. The root surface was sterilized with
1\% chloramines for 15 min (Patriquin et al., 1987), then the roots were rinsed with sterilized distilled water. Fluorescent pseudomonads were obtained by shaking 10 $\mathrm{g}$ of roots in $10 \mathrm{ml}$ of King's B (KB) broth for 3hours at $180 \mathrm{rpm}$ and $28^{\circ} \mathrm{C}$ in a rotary shaker. Serial dilutions of the root suspension $(100 \mu \mathrm{l})$ were plated onto $\mathrm{KB}$ agar (Kings et al., 1954) and incubated for 2 days at $28^{\circ} \mathrm{C}$. The colonies were selected based on the presence of fluorescent green under UV light (366 nm).

Screening and Quantification of bacteria for antagonistic activity against phytopathogenic fungi

All selected fluorescent pseudomonad were tested in vitro for antagonism towards fungal pathogens; Rhizoctonia solani AG 2-2, Pythium arrhenomanes and Fusarium solani. The phytopathogenic fungi were obtained from a stock reference cultures held in of Laboratory of phytopathology, Faculty of Biotechnology, Ghent University, Belgium. The antagonistic activity of selected fluorescent pseudomonad against these phytopathogenic fungi was tested on PDA plates using a dual culture technique (Skidmore and Dickinson, 1976). Observation on width of inhibition zone and mycelia growth of test pathogen was recorded and the percentage of inhibition of pathogen growth was calculated by using the formula proposed by (Vincent, 1927).

Percentage ofinhibition $=\frac{C-T}{C} \times 100$

Where

C: Diameter of pathogen mycelial growth $(\mathrm{mm})$ in control

T: Diameter of pathogen mycelial growth of pathogen in dual plate.

Phenotypic characterization of antagonistic pseudomonads

Based on the percentage of inhibition mycelial growth of tested phytopathogenic fungi, thirty-four 
isolates were selected and examined for phenotypic characters viz Gram stain, oxidation-fermentation reaction, arginine dihydrolase, cytochrome $\mathrm{C}$ oxidase, catalase, fluorescent pigment, citrate utilization and examined for growth at $4^{\circ} \mathrm{C}$ and $42^{\circ} \mathrm{C}$ according to (Mac Faddin,1980).

Molecular method for identification antagonistic fluorescent pseudomonads by rpob primer

In colony polymerase chain reactions (PCR) bacterial cells were directly added to a PCR reaction without extraction of DNA. After touching the colony, place the tip in $20 \mu \mathrm{L}$ of sterilized milli-q water (in a clean PCR tube) and pipette up and down several times and label the tube with a colony number (Grunenwald, 2000). The PCR were performed using the primers rpob, rpoBf1CAGTTCATGGACCAGAACAACCCGCT and rpoBr1 CCCATCAACGCACGGTTGGCGTC. The PCR reaction mixture consisted of $1 \mu$ template DNA, $0.25 \mu \mathrm{l}$ Taq DNA polymerase, $10 \mu \mathrm{l} 5 \mathrm{x}$ reaction buffer, $2.5 \mu \mathrm{l}$ of each primer, $1 \mu \mathrm{l} \mathrm{dNTPs}$ and add $\mathrm{H}_{2} \mathrm{O}$ to a final volume of $50 \mu \mathrm{l}$. The thermo cycling was programmed at $94^{\circ} \mathrm{C}$ for $10 \mathrm{~min}$, was followed by 35 cycles of $1 \mathrm{~min}$ denaturation at $94^{\circ} \mathrm{C}$, annealing at $54^{\circ} \mathrm{C}$ for $1 \mathrm{~min}$, extension bat $72^{\circ} \mathrm{C}$ for $1 \mathrm{~min}$, and final extension of 10 minutes at $72^{\circ} \mathrm{C}$. The $10 \mu \mathrm{L}$ of each extracted DNA sample was firstly mixed with $2.5 \mu \mathrm{L}$ ethidium bromide and $12.5 \mu \mathrm{L}$ of each sample was applied to a well on the on $1 \%$ agarose gel along with $1 \mathrm{~kb}$ ladder as marker in a tray filled with 1xTAE buffer. The PCR results were visualized as bands on the gel during ultraviolet illumination.

All PCR products were purified using the QIAGEN MinElute ${ }^{\circledR}$ PCR Purification Kit. The purified products were directly sequenced; the obtained sequences were aligned using Bioedit programe (http://www.mbio.ncsu.edu/bioedit/bioedit.html). The BLAST database of the National Center for Biotechnology Information (NCBI) was used to compare resolved sequences of the 20 isolates with rpob sequences data deposited in Gene bank. A phylogenetic tree was constructed by using the software MEGA5 (http://www.megasoftware.net/).

\section{Detection of hydrogen cyanide}

Production of hydrogen cyanide was detected using the method of (Reddy et al., 2008).

\section{Indole acetic acid (IAA) production}

IAA production by the selected fluorescent pseudomonad was detected qualitatively by the modified method as described by (Brick et al., 1991) and quantitatively in the presence of L-tryptophan (LTRP) by colorimetric method (Sarwar et al., 1992).

\section{Phosphate solubilizing activity}

The ability of selected fluorescent pseudomonad to solubilize insoluble inorganic phosphate was estimated using qualitative and quantitative methods. For qualitative method, the bacterial isolates were streaked onto Pikovskaya's agar medium (Pikovskaya, 1948) containing tricalcium phosphate as insoluble inorganic phosphate. After 7 days of incubation at $28^{\circ} \mathrm{C}$, the halo zone around the colony was confirmation of phosphate solubilization. The ability of fluorescent pseudomonad isolates to solubilize insoluble phosphate was tested quantitatively in liquid culture. Quantitative estimation of phosphate solubilization was carried out according to Jackson (1973).

\section{Pot experiment}

The soil used in this experiment was a mixture of sand and soil (Structural; Snebbout, Kaprijke, Belgium) (50/50, w/w). Bean seeds of Phaseolus vulgaris $c v$. Prelude (Het Vlaams Zaadhuis, Waarshoot, Belgium) were pre-germinated before sowing. Bean seeds were surface sterilized using $1 \%$ sodium hypochlorite solution for $5 \mathrm{~min}$, rinsed thrice in sterile distilled water and about 25 seeds each were placed on wet filter paper in Petri dishes. The seeds were incubated at $28^{\circ} \mathrm{C}$ for 3 days prior to the setting up of the experiment. The fungus strains used in this experiment were $R$. Solani AG 2-2, Pythium arrhenomanes and Fusarium solani. To produce fungus inoculum, sterilized kernels were inoculated with actively growing hyphae from a 3 days old PDA culture of fungus. Flasks were kept in the incubator at $28{ }^{\circ} \mathrm{C}$ for two weeks prior to the setting up of the plant experiment. Four bacterial strains were used in this experiment; Pseudomonas entomophila SAW7, Pseudomonas putida SAW19, Pseudomonas palleroniana SAW15 and Pseudomonas mosselii SAW1. The bacterial populations were adjusted by adding appropriate amounts of saline solution, to obtain $2800 \times 10^{6}$ CFU per $200 \mathrm{ml}$. These dilutions served as bacterial inoculums for the plant experiment. Twenty $\mathrm{ml}$ diluted bacterial suspension was mixed thoroughly with $2.8 \mathrm{~kg}$ of soil for $2 \mathrm{~min}$. Four perforated plastic boxes $(22 \times 15 \times 6 \mathrm{~cm})$ were partially filled with $700 \mathrm{~g}$ of soil. Thus, there were four replicates for each treatment was done. Soil mixed with $200 \mathrm{ml}$ saline solution served as positive and negative controls. Ten pre-germinated bean seeds were sown in each box and all plants were incubated in a growth chamber $\left(28^{\circ} \mathrm{C}\right.$, relative humidity of $70 \%, 16 \mathrm{~h}$ photoperiod). The plants were daily watered to maintain soil moisture. Three days after sowing, 40 wheat kernels colonized with fungus were placed in each box at a depth of approximately $2 \mathrm{~cm}$ and $3 \mathrm{~cm}$ away from the bean seedlings. The positive control was not inoculated with wheat kernels. The negative control was inoculated with wheat kernels and without antagonistic bacteria. The plants were harvested after 30 days from sowing date and some growth parameters were recorded as well disease severity (Fang et al., 2011).

\section{Isolation and screening of antagonistic fluorescent pseudomonads}

A total of 200 isolates of fluorescent pseudomonads were isolated from root samples of different crops (wheat, bean, clover, tomato and Mango).The fungal growth inhibition by tested bacterial isolates was assessed by measuring the inhibition of mycelia radial growth in the dual culture plate assay against the three phytopathogenic fungi namely Rhizoctonia solani AG 2-2, Fusarium solani and Pythium arrhenomanes (Table 1). 
Table (1): Antifungal activity of fluorescent pseudomonad isolates against phytopathogenic fungi used in the study

\begin{tabular}{|c|c|c|c|c|c|c|}
\hline \multirow{2}{*}{ Isolates } & \multicolumn{2}{|c|}{ Rhizoctonia solani $A G$ 2-2 } & \multicolumn{2}{|c|}{ Fusarium solani } & \multicolumn{2}{|c|}{ Pythium arrhenomanes } \\
\hline & $\mathbf{m m}^{\dagger}$ & $\%^{\ddagger}$ & $\mathbf{m m}^{\dagger}$ & $\%^{*}$ & $\mathbf{m m}^{\dagger}$ & $\%$ \\
\hline SAW7 & $17.1^{1}$ & $78.7^{\mathrm{c}}$ & $17.1^{\mathrm{h}}$ & $78.7^{\mathrm{c}}$ & $12.1^{\mathrm{n}}$ & $84.8^{\mathrm{a}}$ \\
\hline SAB1 & $32.1^{\mathrm{f}}$ & $60^{\mathrm{i}}$ & $22.1^{\mathrm{g}}$ & $72.5^{\mathrm{d}}$ & $22.1^{\mathrm{k}}$ & $72.5^{\mathrm{d}}$ \\
\hline SAW1 & $24.6^{\mathrm{i}}$ & $69.3^{\mathrm{f}}$ & $14.6^{\mathrm{i}}$ & $81.8^{\mathrm{b}}$ & $24.6^{\mathrm{i}}$ & $69.3^{\mathrm{f}}$ \\
\hline SAC1 & $37.1^{\mathrm{b}}$ & $53.7^{1}$ & $17.1^{\mathrm{h}}$ & $78.7^{\mathrm{c}}$ & $19.6^{1}$ & $75.6^{\mathrm{c}}$ \\
\hline SAW6 & $29.6^{\mathrm{g}}$ & $63.1^{\mathrm{h}}$ & $29.6^{\mathrm{d}}$ & $63.1^{\mathrm{g}}$ & $27.1^{\mathrm{h}}$ & $66^{\mathrm{g}}$ \\
\hline SAB17 & $24.6^{\mathrm{i}}$ & $69.3^{\mathrm{f}}$ & $29.6^{\mathrm{d}}$ & $63.1^{\mathrm{g}}$ & $27.1^{\mathrm{h}}$ & $66.2^{\mathrm{g}}$ \\
\hline SAB7 & $34.1^{\mathrm{d}}$ & $57.5^{\mathrm{j}}$ & $80^{\mathrm{a}}$ & $0^{\mathrm{j}}$ & $80^{\mathrm{a}}$ & $0^{\mathrm{m}}$ \\
\hline SAB15 & $27.1^{\mathrm{h}}$ & $66.2^{\mathrm{g}}$ & $24.6^{\mathrm{f}}$ & $69.3^{\mathrm{e}}$ & $27.1^{\mathrm{h}}$ & $66.2^{\mathrm{g}}$ \\
\hline SAB9 & $22.1^{\mathrm{j}}$ & $72.5^{\mathrm{e}}$ & $32.1^{\mathrm{c}}$ & $60^{\mathrm{h}}$ & $34.6^{\mathrm{b}}$ & $56.8^{1}$ \\
\hline SAC6 & $34.1^{\mathrm{d}}$ & $57.5^{\mathrm{j}}$ & $24.6^{\mathrm{f}}$ & $69.3^{\mathrm{e}}$ & $24.6^{\mathrm{i}}$ & $69.3^{\mathrm{f}}$ \\
\hline SAB11 & $33.6^{\mathrm{e}}$ & $58.1^{\mathrm{j}}$ & $32.1^{\mathrm{c}}$ & $60^{\mathrm{h}}$ & $34.6^{\mathrm{b}}$ & $56.8^{1}$ \\
\hline SAC8 & $39.6^{\mathrm{a}}$ & $50^{\mathrm{m}}$ & $32.1^{\mathrm{c}}$ & $60^{\mathrm{h}}$ & $32.1^{\mathrm{d}}$ & $60^{j}$ \\
\hline SAC13 & $29.4^{\mathrm{g}}$ & $63.1^{\mathrm{h}}$ & $27.1^{\mathrm{e}}$ & $66.2^{\mathrm{f}}$ & $80^{\mathrm{a}}$ & $0^{\mathrm{m}}$ \\
\hline SAC14 & $37.1^{\mathrm{b}}$ & $53.7^{1}$ & $32.1^{\mathrm{c}}$ & $60^{\mathrm{h}}$ & $29.1^{\mathrm{f}}$ & $63.7^{\mathrm{h}}$ \\
\hline SAC14 & $34^{\mathrm{d}}$ & $57.5^{\mathrm{j}}$ & $27.1^{\mathrm{e}}$ & $66.2^{\mathrm{f}}$ & $24.1^{\mathrm{j}}$ & $70^{\mathrm{e}}$ \\
\hline SAB16 & $29.6^{\mathrm{g}}$ & $63.1^{\mathrm{h}}$ & $80^{\mathrm{a}}$ & $0^{\mathrm{j}}$ & $80^{\mathrm{a}}$ & $0^{\mathrm{m}}$ \\
\hline SAB14 & $27.1^{\mathrm{h}}$ & $66.2^{\mathrm{g}}$ & $24.6^{\mathrm{f}}$ & $69.3^{\mathrm{e}}$ & $19.6^{1}$ & $75.6^{\mathrm{c}}$ \\
\hline SAB12 & $24.6^{\mathrm{i}}$ & $69.3^{\mathrm{f}}$ & $22.1^{\mathrm{g}}$ & $72.5^{\mathrm{d}}$ & $22.1^{\mathrm{k}}$ & $72.5^{\mathrm{c}}$ \\
\hline SAB8 & $22.1^{\mathrm{j}}$ & $72.5^{\mathrm{e}}$ & $27.1^{\mathrm{e}}$ & $66.2^{\mathrm{f}}$ & $34.1^{\mathrm{c}}$ & $57.5^{\mathrm{k}}$ \\
\hline SAB10 & $27.1^{\mathrm{h}}$ & $66.2^{\mathrm{g}}$ & $22.1^{\mathrm{g}}$ & $72.5^{\mathrm{d}}$ & $22.1^{\mathrm{k}}$ & $72.5^{\mathrm{c}}$ \\
\hline SAB21 & $27.1^{\mathrm{h}}$ & $66.2^{\mathrm{g}}$ & $39.6^{\mathrm{b}}$ & $50^{\mathrm{i}}$ & $29.6^{\mathrm{e}}$ & $63.1^{\mathrm{h}}$ \\
\hline SAW3 & $27.1^{\mathrm{h}}$ & $66.2^{\mathrm{g}}$ & $17.1^{\mathrm{h}}$ & $78.7^{\mathrm{c}}$ & $32.1^{\mathrm{d}}$ & $60^{\mathrm{j}}$ \\
\hline SAW23 & $24.6^{\mathrm{i}}$ & $69.3^{\mathrm{f}}$ & $32.1^{\mathrm{c}}$ & $60^{\mathrm{h}}$ & $29.1^{\mathrm{f}}$ & $63.7^{\mathrm{h}}$ \\
\hline SAW24 & $34.6^{\mathrm{c}}$ & $56.8^{1}$ & $17.1^{\mathrm{h}}$ & $78.7^{\mathrm{c}}$ & $24.6^{\mathrm{i}}$ & $69.3^{\mathrm{f}}$ \\
\hline SAW21 & $19.6^{\mathrm{k}}$ & $75.6^{\mathrm{d}}$ & $29.6^{\mathrm{d}}$ & $63.1^{\mathrm{g}}$ & $29.6^{\mathrm{e}}$ & $63.1^{\mathrm{i}}$ \\
\hline SAW22 & $27.1^{\mathrm{h}}$ & $66.2^{\mathrm{g}}$ & $9.6^{\mathrm{j}}$ & $88.1^{\mathrm{a}}$ & $32.1^{\mathrm{d}}$ & $60^{\mathrm{j}}$ \\
\hline SAW27 & $29.6^{\mathrm{g}}$ & $63.1^{\mathrm{h}}$ & $32.1^{\mathrm{c}}$ & $60^{\mathrm{h}}$ & $32.1^{\mathrm{d}}$ & $60^{j}$ \\
\hline SAW19 & $4.6^{\mathrm{n}}$ & $94.3^{\mathrm{a}}$ & $14.6^{\mathrm{i}}$ & $81.8^{\mathrm{b}}$ & $14.6^{\mathrm{m}}$ & $81.8^{\mathrm{b}}$ \\
\hline SAC29 & $27.1^{\mathrm{h}}$ & $66.2^{\mathrm{g}}$ & $17.1^{\mathrm{h}}$ & $78.7^{\mathrm{c}}$ & $80^{\mathrm{a}}$ & $0^{\mathrm{m}}$ \\
\hline SAW15 & $24.6^{\mathrm{i}}$ & $69.3^{\mathrm{f}}$ & $14.6^{\mathrm{i}}$ & $81.8^{\mathrm{b}}$ & $27.1^{\mathrm{h}}$ & $66.2^{\mathrm{g}}$ \\
\hline SAC31 & $14.6^{\mathrm{m}}$ & $81.8^{\mathrm{b}}$ & $80^{\mathrm{a}}$ & $0^{\mathrm{j}}$ & $34.6^{\mathrm{b}}$ & $56.8^{1}$ \\
\hline SAW10 & $17.1^{1}$ & $78.7^{\mathrm{c}}$ & $27.1^{\mathrm{e}}$ & $66.2^{\mathrm{f}}$ & $27.8^{\mathrm{g}}$ & $65.5^{\mathrm{i}}$ \\
\hline SAW9 & $27.1^{\mathrm{h}}$ & $66.2^{\mathrm{g}}$ & $39.6^{\mathrm{b}}$ & $50^{\mathrm{i}}$ & $19.6^{1}$ & $75.6^{\mathrm{c}}$ \\
\hline SAW5 & $32.1^{\mathrm{f}}$ & $60^{\mathrm{i}}$ & $22.1^{\mathrm{g}}$ & $72.5^{\mathrm{d}}$ & $27.1^{\mathrm{h}}$ & $66.2^{\mathrm{g}}$ \\
\hline
\end{tabular}

${ }^{\dagger}$ : mycelial growth, ${ }^{\sharp}$ : Percentage of fungal growth inhibition. Values followed by the same letters at the same column are not significantly different by LSD test at 0.05 level.

Thirty-four isolates were showed a broad-spectrum antifungal activity towards tested phytopathogenic fungi. The zone of inhibition of mycelia growth of the above fungal pathogens ranged from 4.6 to $39.6 \mathrm{~mm}$ (Table 1). Specifically, the zone of inhibition of mycelia growth of the fungal pathogen, Rhizoctonia solani AG 
2-2, Fusarium solani and Pythium arrhenomanes, ranged from 4.6 to $39.6 \mathrm{~mm}, 9.6$ to $39.6 \mathrm{~mm}, 12.1$ to $34.6 \mathrm{~mm}$, respectively (Table 4). These findings are similar to those of Saber et al. (2015) who found that the reduction percentages of the mycelial growth of Rhizoctonia solni were $45.45 \%$ and $32.72 \%$ using fluorescent pseudomonads isolate OL2 and AR10, respectively. Toppo and Tiwari (2015) found that four Pseudomonas spp. isolates, Pseudomonas syringae (PKS10), Pseudomonas syringae (PKM11), Pseudomonas alcaligenes (PKJ25), Pseudomonas alcaligenes (PKB27) in addition to Pmtcc (Pseudomonas isolate for standard check) inhibited the hyphal growth of Rhizoctonia solani by 47.67, 49.58, $62.60,53.28$ and $55.47 \%$, respectively. The obtained results concerning the effect of fluorescent pseudomonad isolates against Fusarium solani are in agreement with those obtained by (Couteaudier and Alabouvette, 1990; Mazzola and Gu, 2002), they found that fluorescent pseudomonads are involved in the natural suppressiveness of some soils to Fusarium wilts of various plant species.

\section{Phenotypic characterization}

Based on the highly antagonistic potential, twenty isolates of fluorescent pseudomonads were selected for examination of phenotypic tests. The results showed that all tested isolates have positive reactions for fluorescence on $\mathrm{KB}$ agar, oxidase, citrate and catalase, while the remained isolates have highly variability for other phenotypic tests such as gelatin hydrolysis, levan production and growth at $4^{\circ} \mathrm{C}$. Only one isolate (SAW22) has positive results for levan production test and eight isolates (SAW7, SAB17, SAW5, SAW23, SAW21, SAW22, SAW15 and SAB15) have positive results for hydrolyze of gelatin. Three isolates (SAW5, SAW21 and SAB8) have ability to reduce nitrate and eleven isolates (SAW1, SAB17, SAB8, SAB10, SAW3, SAW23, SAW24, SAW21, SAW9, SAW19 and SAW22) have ability to grow at $4^{\circ} \mathrm{C}$. On the other hand, all isolates could not grow at $42^{\circ} \mathrm{C}$ (Table 2).

Concerning to assimilation of carbohydrates, all strains utilized dextrose but exhibited varying degree of utilization towards other carbon sources such as mannitol, sucrose, fructose, L-arabinose, glycerol and xylose. Four isolates (SAW5, SAW9, SAW3 and SAB17) can utilize mannitol whereas one isolate (SAB15) can utilize sucrose. Five isolates (SAW7, SAW5, SAW21, SAW9 and SAB17) canutilize fructose. All isolates were able to utilize xylose as carbon source except (SAB1 and SAW15). Twelve isolates can be utilizing glycerol as carbon source (SAW7, SAB1, SAW1, SAB17, SAB15, SAB14, SAB12, SAB10, SAW21, SAW15, SAW10 and SAW5). All the isolates were unable to utilize sorbose, sorbitol, maltose and adonitol (Table 2).

\footnotetext{
Molecular method for identification antagonistic fluorescent pseudomonads by rpob primer.

Phylogenetic tree obtained with rpob sequences determined in this study for the same strains (Fig. 1). On the basis of BLAST analysis of rpob gene (about 1000
}

bp) the homology of fluorescent pseudomonad species such as $P$. palleroniana, $P$. aeruginosa, $P$. putida, $P$. entomophila and $P$. moraviensis ranged from (96 to $100 \%)$. The analysis of sequences showed two strains (SAW7 and SAW5) belonged to $P$. entomophila, five strains (SAW19, SAW22, SAB12, SAW3 and SAB10) belonged to $P$. putida, three strains (SAB15, SAW21 and SAB17) belonged to $P$. palleroniana, two strains (SAC1 and SAW23) belonged to $P$. corrugata, one strain (SAW15) belonged to $P$. moraviensis, one isolate (SAW1) belonged to Pseudomonas mosselii and three strains (SAW10, SAB1 and SAB8) belonged to $P$. plecoglossicida.

Phylogenetic analyses of 20 representative fluorescent pseudomonad isolates based on neighborjoining method with 1000 bootstrap sampling resulted in five major groups Fig. (1). of the 20 isolates, group (I) was formed by three strains of Pseudomonas palleroniana (SAB15, SAW21, SAB17) and one strain of Pseudomonas moraviensis (SAW15), group (II) was formed by one strain Pseudomonas anguilliseptica (SAW24), group (III) was formed by strains, representing the major group, 2 strains of Pseudomonas entomophila (SAW7 and SAW5), one strain of Pseudomonas parafulva (SAB14), three strains of Pseudomonas plecoglossicida (SAW10, SAB1 and SAB8), one strain of Pseudomonas mosselii (SAW1) and five strains of Pseudomonas putida (SAW19, SAW22, SAB12, SAW3 and SAB10), group (IV) was formed by 1 strain of Pseudomonas argentinensis (SAW9) and group (V) was formed by 2 strains of Pseudomonas corrugate (SAC1 and SAW23).

\section{Indole acetic acid (IAA) production.}

In qualitative method, the results in Table (3) indicate that eight strains (Pseudomonas entomophila SAW7, Pseudomonas mosselii SAW1, Pseudomonas parafulva SAB14, Pseudomonas corrugate SAW23, Pseudomonas anguilliseptica SAW24, Pseudomonas putida SAW19, Pseudomonas argentinensis SAW9 and Pseudomonas entomophila SAW5) were able to produce IAA. In quantitative determination, IAA production by antagonistic fluorescent pseudomonas isolates ranged from 7.84-19.59 $\mathrm{mgl}^{-1}$. SAW1 exhibit highest IAA production $19.59 \mathrm{mgl}^{-1}$ (Table 3). On the other hand, the strain SAW23which was identified as Pseudomonas corrugata produced the lowest auxin value $\left(7.84 \mathrm{mgl}^{-1}\right)$. The differences in the performance of auxin-producing fluorescent pseudomonads may be attributed to the inherent properties of the individual bacteria (Sarwar et al., 1992). Similar results regarding variation in the ability to biosynthesize auxin among fluorescent pseudomonads, many investigators also have reported that auxin production by microbial isolates greatly varied within species and/or strains of the same species (Asghar et al., 2002; Khalid et al., 2004; Ahmed et al., 2005). Additionally, several studies reported that IAA production is widespread by $P$. aeruginosa, $P$. chlororaphis, $P$. fluorescens, $P$. putida, $P$. syringae and P. stutzeri (Patten and Glick, 2002; Lucas García et al., 2003; Pedraza et al., 2004; Ayyadurai et al., 2006, 2008; Karnwal, 2009). 


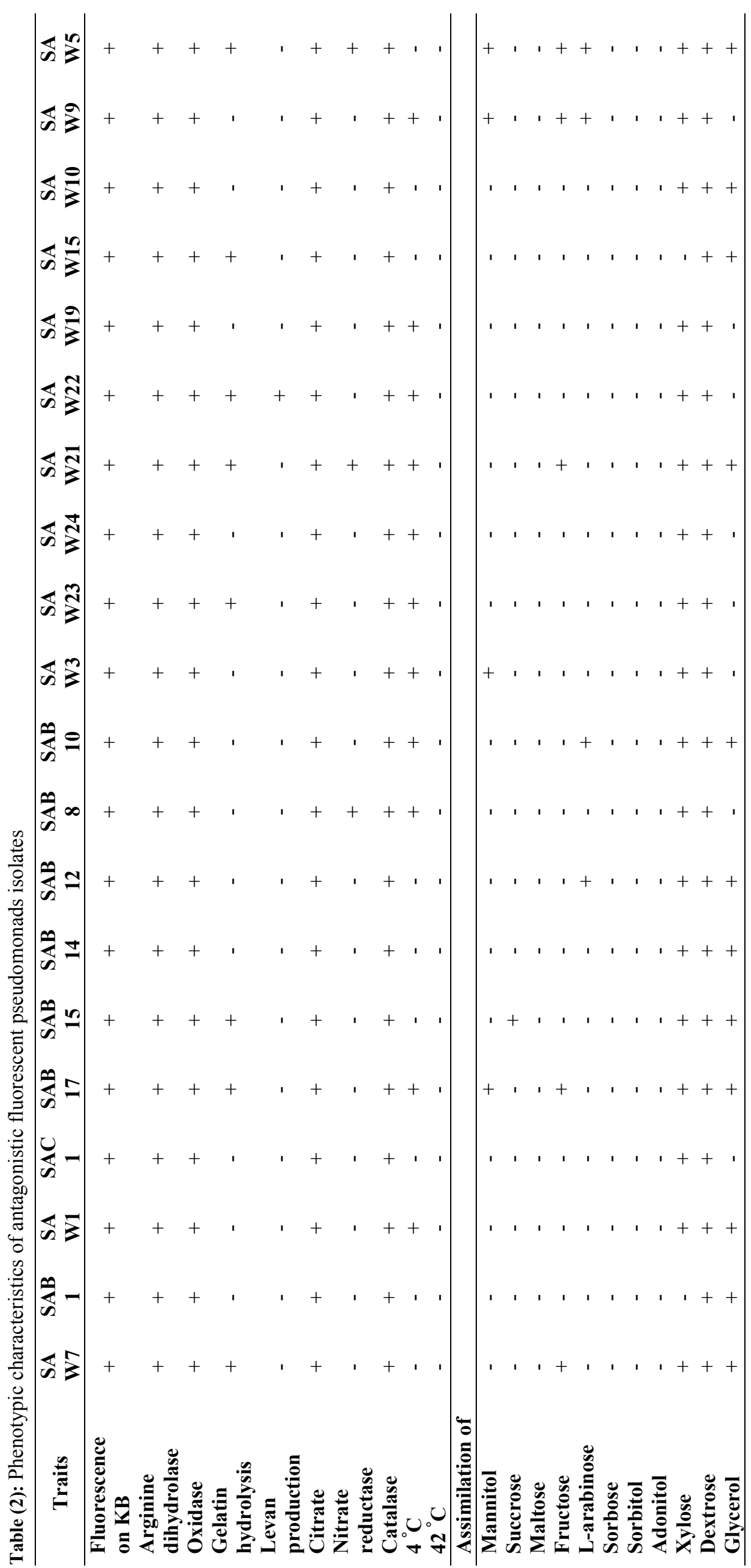




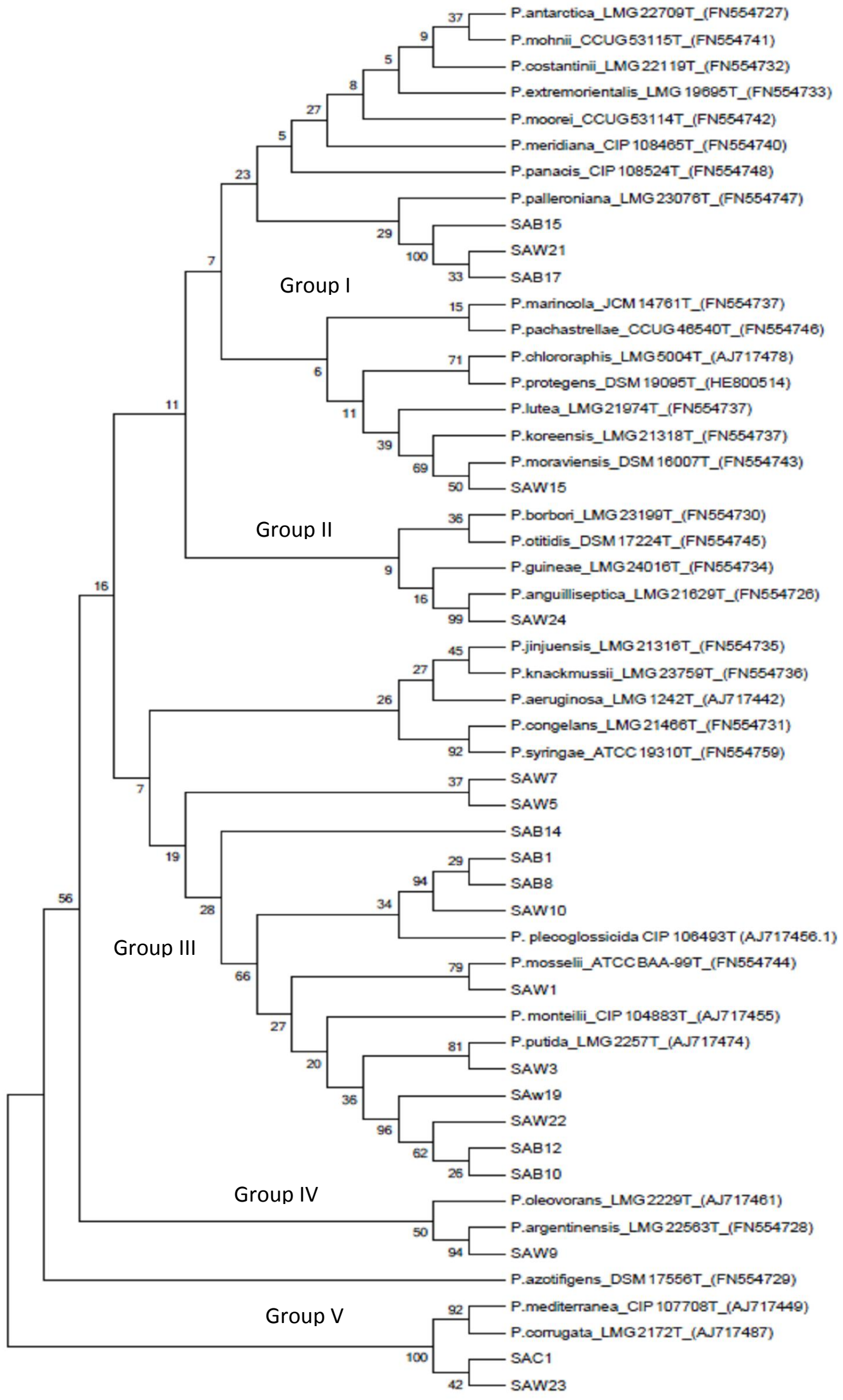

Fig. (1): Phylogenetic tree of 20 antagonistic fluorescent pseudomonad strains based on the rpob sequences. 


\section{Phosphate solubilizing activity}

Qualitative determination of phosphate-solubilizing capacity of the tested fluorescent pseudomonads strains show that thirteen of the tested twenty strains $(65.0 \%)$ were able to solubilize of $\mathrm{Ca}_{3}\left(\mathrm{PO}_{4}\right)_{2}$ (Table 3). These strains are Pseudomonas plecoglossicida SAB1, Pseudomonas corrugata SAC1, Pseudomonas palleroniana SAB17, Pseudomonas palleroniana SAB15, Pseudomonas corrugata SAW23, Pseudomonas palleroniana SAW21, Pseudomonas putida SAW22, Pseudomonas moraviensis SAW15, Pseudomonas putida SAB12, Pseudomonas plecoglossicidaSAB8, Pseudomonas plecoglossicida SAB10, Pseudomonas putida SAW3, and Pseudomonas plecoglossicida SAW10. The quantitative estimation of phosphate solubilization showed diverse levels of phosphate solubilizing activity. After an incubation period of 7 days, the amounts of $\mathrm{P}$ solubilized from $\mathrm{Ca}_{3}$ $\left(\mathrm{PO}_{4}\right)_{2}$ by the tested strains ranged from 12.75 to 131.11 $\mathrm{mg} \mathrm{Pl}{ }^{-1}$ and the $\mathrm{pH}$ values of the cultures were reduced from initial value of 7.1 to values varied between 4.20 and 5.87. Strain SAB12was the most efficient strain in solubilizing of phosphate and in decreasing $\mathrm{pH}$ value (Table 3). On the other hand, the strain SAW23 was the lowest efficient strain in solubilizing of phosphate (12.57 mg $\mathrm{P} \mathrm{l}^{-1}$ ). The decrease in $\mathrm{pH}$ values clearly indicates the production of organic acids, which is considered to be the mechanism responsible for $\mathrm{P}$ solubization (Rodriguez et al., 2004). Similar results were confirmed by previous works by (Kpomblekou and Tabatabai, 1994; Nautiyal et al., 2000). In addition to organic acids, other mechanisms such as inorganic acids, chelating agents and mineralization of organic phosphorus may be also responsible for solubilization of phosphate. Previous studies reported that several species of fluorescent pseudomonads such as $P$. fluorescens $\mathrm{NJ}$ 101 and EM85 (Bano and Musarrat, 2004; Dey et al., 2004), ), P. aeruginosa (Bano and Musarrat, 2004), Pseudomonas sp. (Leinhos, 1994), P. chlororaphis, P. savastanoi, $P$. pickettii (Cattelan et al., 1999), P. lutea OK2 (Peix et al., 2003), P. rhizophaerae LMG 21640, P. graminis DSM 11363 (Peix et al., 2003), P. striata (Gaind and Gaur, 2002) and $P$. corrugate (Pandey and Palni, 1998) have been reported as efficient phosphate solubilizers.

\section{Production of hydrogen cyanide (HCN)}

Hydrogen cyanide production was observed after $96 \mathrm{~h}$ for strains, the $\mathrm{HCN}$ formed a brownish red compound with sodium picrate. In the present study, seven strains produced HCN (Pseudomonas entomophila SAW7, Pseudomonas mosselii SAW1, Pseudomonas corrugate SAC1, Pseudomonas moraviensis SAW15, Pseudomonas palleroniana SAB17, Pseudomonas parafulva SAB14, and Pseudomonas palleroniana SAW21) (Table 3). HCN production has been evidenced in several Pseudomonas species (P. fluorescens, P. aeruginosa, P. chlororaphis, and $P$. aureofaciens), (Haas and Defago, 2005).

\section{Cultivation experiment}

Plant response to inoculation with the selected four antagonistic Pseudomonas strains was evaluated by measuring some growth parameters after 30 days from sowing date. These parameters include plant height, fresh and dry weight (Table 4). The results in Table (4) show that all tested strains significantly increased plant height ranging from $65.47 \%$ with the strain SAW15 to $112.39 \%$ with SAW19 strain when compared to the negative control (diseased treatment). However, the differences between these four strains were not statistically significant (Table 4). Bean plants treated with four Pseudomonas strains (SAW1, SAW15, SAW19 and SAW7) without any infection of fungus showed plant growth promoting effect of these bacteria for all tested growth parameters. Moreover, the results showed that the plant treated with tested phytopathogenic fungi (the diseased treatment) significantly decreased the plant height compared to the plant treated with tested Pseudomonas strains. Obtained results indicated that the highest value of plant height $(68 \mathrm{~cm})$ was pronounced with SAW19 strain, which identified as $P$. putida in soil infested with $R$. solani AG 2-2.

Regarding the dry weight of the bean, data presented in Table (4) indicated that fresh and dry weights of bean plants were highly affected by inoculation with different Pseudomonas strains. Generally, the highest plant fresh weight (23.3 $\left.\mathrm{g} \mathrm{pot}^{-1}\right)$ was observed when plant inoculated with SAW15 strain, which identified as Pseudomonas palleroniana, and infected with $F$. solni. Similarity, the highest plant dry weight $\left(10.3 \mathrm{~g} \mathrm{pot}^{-1}\right)$ was observed when plant inoculated with SAW15 and SAW19 strains, which identified as Pseudomonas palleroniana and Pseudomonas putida, when soil infected with $R$. solani AG 2-2 and F. solni, respectively. Additionally, inoculation with the Pseudomonas strains without any infection with phytopathogenic fungi led to an improvement in the plant fresh and dry weights when compared to diseased treatment. Based on the results of this study, the application of biocontrol agents of fluorescent pseudomonads significantly promoted plant vigor and health. These findings were primarily due to the positive effects of the tested Pseudomonas strains on plant growth that are always correlated with noteworthy changes in root morphology such as increased lateral root length and root hair number and length. In this regard, some plant growth-promoting bacteria Pseudomonas sp. strain promote root development and alter root architecture by the production of phytohormones such as IAA, cytokinins, and gibberellins (Bloemberg and Lugtenberg 2001; Persello-Cartieaux et al., 2003). Plant-growth promotion for some rhizobacteria has been found to be related with the solubilization and increased uptake of phosphate (Gyaneshwar et al., 2002). These findings are in agreement with the results in this study because of the tested three strains (SAW1, SAW19 and SAW7) have ability to produce IAA and one strain has induced to solubilize insoluble inorganic phosphate (Table 4). Obtained results also are similar to those of Saber, Fekria et al. (2015), who found that the inoculation of tomato seedlings with Pseudomonas strains led to support plant growth and increased of NPK uptake. Previous studies have shown that rhizobacteria had positive response on plant growth and plant health (Naureen Zakira, 2009; Erdogan and Benlioglu, 2010). 
Table (3): Plant growth promoting activities of antagonistic fluorescent pseudomonads

\begin{tabular}{|c|c|c|c|c|c|c|}
\hline \multirow{2}{*}{ strains } & \multicolumn{3}{|c|}{ P-Solubilization } & \multicolumn{2}{|c|}{$\begin{array}{c}\text { IAA }^{\dagger} \text { production ( } \\
\left.\text { mgl }^{-1}\right)\end{array}$} & \multirow{2}{*}{$\mathrm{HCN}^{\mathrm{s}}$} \\
\hline & $\begin{array}{l}\text { On solid } \\
\text { medium }\end{array}$ & pH & $\underset{\mathbf{I}^{-1}}{\operatorname{mg} P}$ & $\begin{array}{c}\text { On liquid } \\
\text { medium }\end{array}$ & $\begin{array}{c}\text { With } \\
\text { L-TRP }^{\dagger \dagger}\end{array}$ & \\
\hline Pseudomonas entomophila SAW7 & - & - & - & + & 13.06 & + \\
\hline Pseudomonas plecoglossicida SAB1 & + & 5.87 & 12.75 & - & - & - \\
\hline Pseudomonas mosselii SAW1 & - & - & - & + & 19.59 & + \\
\hline Pseudomonas corrugata SAC1 & + & 5.66 & 70.60 & - & - & + \\
\hline Pseudomonas palleroniana SAB17 & + & 4.68 & 105.02 & - & - & + \\
\hline Pseudomonas palleroniana SAB15 & + & 5.55 & 87.62 & - & - & - \\
\hline Pseudomonas parafulva SAB14 & - & - & - & + & 16.98 & + \\
\hline Pseudomonas putida SAB12 & + & 4.2 & 131.11 & - & - & - \\
\hline Pseudomonas plecoglossicida SAB8 & + & 4.55 & 119.52 & - & - & - \\
\hline Pseudomonas putida SAB10 & + & 4.34 & 127.58 & - & - & - \\
\hline Pseudomonas putida SAW3 & + & 5.22 & 82.32 & - & - & - \\
\hline Pseudomonas corrugata SAW23 & + & 5.30 & 79.68 & + & 7.84 & - \\
\hline Pseudomonas anguilliseptica SAW24 & - & - & - & + & 10.45 & - \\
\hline Pseudomonas palleroniana SAW21 & + & 4.90 & 100.73 & - & - & + \\
\hline Pseudomonas putida SAW22 & + & 4.65 & 102.24 & - & - & - \\
\hline Pseudomonas putida SAW19 & - & - & - & + & 15.67 & - \\
\hline Pseudomonas moraviensis SAW15 & + & 5.44 & 89.63 & - & - & + \\
\hline Pseudomonas plecoglossicida SAW10 & + & 5.17 & 96.44 & - & - & - \\
\hline Pseudomonas argentinensis SAW9 & - & - & - & + & 11.75 & - \\
\hline Pseudomonas entomophila SAW5 & - & - & - & + & 14.36 & - \\
\hline
\end{tabular}

${ }^{\dagger}$ IAA: Indole acetic acid, ${ }^{\dagger} \mathrm{L}-\mathrm{TRP}:$ L-tryptophan, ${ }^{5} \mathrm{HCN}$ : Hydrogen cyanide 
Table (4): Effect of Pseudomonas strains on plant growth of bean plants with three different phytopathogenic fungi

\begin{tabular}{|c|c|c|c|c|c|c|c|c|c|}
\hline \multirow[b]{2}{*}{ Strains } & \multicolumn{3}{|c|}{ Plant height (cm) } & \multicolumn{3}{|c|}{ Plant fresh weight (g) } & \multicolumn{3}{|c|}{ Plant dry weight (g) } \\
\hline & 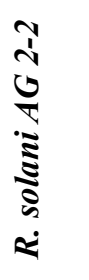 & 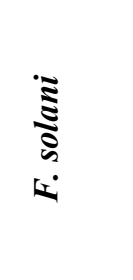 & 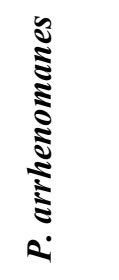 & 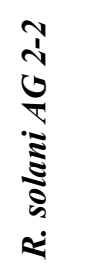 & 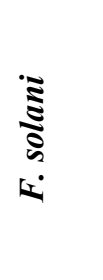 & 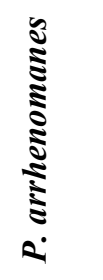 & 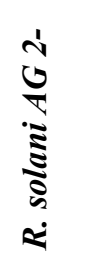 & 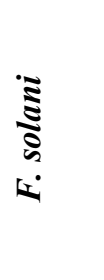 & 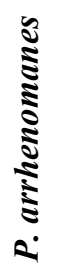 \\
\hline $\begin{array}{l}\text { Pseudomonas } \\
\text { mosselii SAW1 }\end{array}$ & $54^{\mathrm{c}}$ & $66^{\mathrm{a}}$ & $55.33^{\mathrm{b}}$ & $18.3^{\mathrm{b}}$ & $22^{\mathrm{a}}$ & $19.8^{\mathrm{a}}$ & $8.3^{\mathrm{a}}$ & $10.1^{\mathrm{a}}$ & $8.9^{\mathrm{a}}$ \\
\hline $\begin{array}{l}\text { Pseudomonas } \\
\text { moraviensis SAW15 }\end{array}$ & $53^{\mathrm{c}}$ & $67^{\mathrm{a}}$ & $55.6^{\mathrm{b}}$ & $17^{\mathrm{b}}$ & $23.3^{\mathrm{a}}$ & $19.4^{\mathrm{a}}$ & $7.2^{\mathrm{ab}}$ & $10.3^{\mathrm{a}}$ & $8.7^{\mathrm{a}}$ \\
\hline $\begin{array}{l}\text { Pseudomonas putida } \\
\text { SAW19 }\end{array}$ & $\begin{array}{c}68.0 \\
3^{\mathrm{a}}\end{array}$ & $65.03^{\mathrm{ab}}$ & $53.16^{\mathrm{b}}$ & $23^{\mathrm{a}}$ & $23^{\mathrm{a}}$ & $18.5^{\mathrm{a}}$ & $10.3^{\mathrm{a}}$ & $10.1^{\mathrm{a}}$ & $7.5^{\mathrm{ab}}$ \\
\hline $\begin{array}{l}\text { Pseudomonas } \\
\text { entomophila SAW7 }\end{array}$ & $60^{\mathrm{b}}$ & $62^{\mathrm{b}}$ & $60^{\mathrm{a}}$ & $20^{\mathrm{ab}}$ & $22^{\mathrm{a}}$ & $17^{\mathrm{a}}$ & $9^{a}$ & $9.5^{\mathrm{a}}$ & $8.9^{\mathrm{a}}$ \\
\hline Diseased & $\begin{array}{c}32.0 \\
3^{\mathrm{d}}\end{array}$ & $35.03^{\mathrm{d}}$ & $34.66^{\mathrm{c}}$ & $12^{\mathrm{c}}$ & $12.2^{\mathrm{c}}$ & $11.8^{\mathrm{b}}$ & $4.3^{\mathrm{b}}$ & $4.5^{\mathrm{b}}$ & $4.3^{\mathrm{b}}$ \\
\hline Healthy Control & $52^{\mathrm{c}}$ & $52^{\mathrm{c}}$ & $52^{\mathrm{b}}$ & $16.8^{\mathrm{b}}$ & $16.8^{\mathrm{b}}$ & $16.8^{\mathrm{a}}$ & $7^{\mathrm{ab}}$ & $7^{\mathrm{ab}}$ & $7^{\mathrm{ab}}$ \\
\hline
\end{tabular}

Values followed by the same letters at the same column are not significantly different by LSD test at 0.05 level.

Table (5): Effect of Pseudomonas strains on Bacterial population of bean with three different phytopathogenic fungi

\begin{tabular}{|c|c|c|c|c|}
\hline \multirow{2}{*}{ Strains } & \multicolumn{4}{|c|}{$\begin{array}{l}\text { Bacterial population } \\
\left(\log C F U g^{-1} \text { fresh root) }\right.\end{array}$} \\
\hline & R. solani $A G$ 2-2 & Fusarium solani & $\begin{array}{c}\text { Pythium } \\
\text { arrhenomanes }\end{array}$ & control \\
\hline SAW1 & $4.5^{b}$ & $5.3^{\mathrm{a}}$ & $5.1^{\mathrm{a}}$ & $3.0^{\mathrm{c}}$ \\
\hline SAW15 & $4.7^{\mathrm{b}}$ & $5.7^{\mathrm{a}}$ & $4.8^{\mathrm{b}}$ & $3.7^{\mathrm{c}}$ \\
\hline SAW19 & $5.6^{\mathrm{b}}$ & $5.5^{\mathrm{a}}$ & $4.3^{b}$ & $3.5^{\mathrm{c}}$ \\
\hline SAW7 & $5.2^{\mathrm{a}}$ & $4.9^{\mathrm{a}}$ & $5.3^{\mathrm{a}}$ & $4.0^{\mathrm{b}}$ \\
\hline
\end{tabular}

Values followed by the same letters at the same row are not significantly different by LSD test at 0.05 level.

Table (6): Effect of Pseudomonas strains on disease severity of bean with three different phytopathogenic fungi

\begin{tabular}{lccc}
\hline \multirow{2}{*}{ Isolates } & \multicolumn{2}{c}{ disease severity } \\
\cline { 2 - 4 } & R. solani AG 2-2 & Fusarium solani & Pythium arrhenomanes \\
\hline SAW1 & $0.15^{\mathrm{b}}$ & $0.0^{\mathrm{c}}$ & $0.0^{\mathrm{d}}$ \\
SAW15 & $0.1^{\mathrm{b}}$ & $0.0^{\mathrm{c}}$ & $0.25^{\mathrm{b}}$ \\
SAW19 & $0.0^{\mathrm{c}}$ & $0.0^{\mathrm{c}}$ & $0.2^{\mathrm{c}}$ \\
SAW7 & $0.0^{\mathrm{b}}$ & $0.1^{\mathrm{b}}$ & $0.0^{\mathrm{d}}$ \\
Healthy control & $0.0^{\mathrm{c}}$ & $0.0^{\mathrm{c}}$ & $0.0^{\mathrm{d}}$ \\
Diseased & $2.2^{\mathrm{a}}$ & $3.5^{\mathrm{a}}$ & $2.33^{\mathrm{a}}$
\end{tabular}

Values followed by the same letters at the same column are not significantly different by LSD test at 0.05 level. 
The role of Pseudomonas spp. in promoting root and shoot growth of different crops has been demonstrated by Kamal et al. (2008).

\section{Bacterial root colonization}

The obtained results showed that all the tested Pseudomonas strains had capacity for root colonization when compared with the control treatment (Table 5). The population densities of Pseudomonas spp. are ranged from 4.5 to $5.7 \log \mathrm{CFU} \mathrm{g}{ }^{-1}$ fresh root. The highest population of bacteria (5.7 $\log \mathrm{CFU} \mathrm{g} \mathrm{g}^{-1}$ root) was observed when bean plant inoculated with SAW15 strain (Pseudomonas palleroniana) and infected with F. solni. Plant root colonization by bacteria can be considered as an enrichment of the best adapted microorganisms to a particular ecological niche. Colonization of roots by inoculated bacteria is an important step in the interaction between beneficial bacteria and the host plant. Seed colonization is the first step in root colonization. Microorganisms established on the germinating seed can multiply and colonize the root as it emerges and grows through soil. Thus colonization of the imbibing seed may predispose future colonization of the root. Previous studies have shown that the fluorescent pseudomonads are aggressive colonizers of the rhizosphere of various crop plants (Weller et al., 2002; Bhattacharyya and Jha, 2012).

\section{Disease severity index}

The pathogenicity of the tested Pseudomonas strains was estimated in the current study by a disease severity index. The index was expressed according to a 4-point disease index scale based on the progressive wilt symptoms. The absence of symptoms was rated zero. Disease severity was significantly but variously affected by the tested four Pseudomonas strains (Table 6). The obtained results indicated that the plants that had inoculated with only fungus had the highest disease index. The average disease severity index values are 2.2, 3.5 and 2.33 for $R$. solani AG 2-2, F. solani and Pythium. arrhenomanes, respectively. The disease index was significantly lower when plants inoculated with SAW1 or SAW15 strains and infected with $R$. solani AG 2-2 (Table 6). The disease index of plants receiving SAW19 or SAW7 strains plus $R$. solani was equal or similar to that in non-treated control and the index value is zero (that is absence of wilt symptoms). The same trend was observed in the plants that inoculated with SAW1 or SAW15 or SAW19 plus $F$. solani and the plants inoculated SAW1 or SAW7 plus Pythium arrhenomanes. A significantly lower disease severity, as compared to treatment with $F$. solani or Pythium arrhenomanes, was also observed in plants treated with SAW7 and plants treated with SAW15 and SAW19 strains, respectively. This indicated that the tested antagonistic fluorescent pseudomonads reduced disease severity in beans and disease development. These results were confirmed the result obtained in vitro antagonistic activity that the colonization of roots by pathogenic fungi was suppressed by with antagonistic strains (Table 6). In general, the results showed that the strains which have ability to colonize the root of plant were more effective in suppressing pathogenic fungi on bean plants.
It seems that performance of rhizobacteria was effective in disease development. This delay may be due to either preliminary induced systemic resistance (Van loon et al., 1998) or preliminary colonization which suppress pathogen onset directly via different mechanisms such as production of antibiotics and volatile compound competition for space or nutrition (Mafia et al., 2009).

\section{CONCLUSION}

The present study clearly indicates the potential of fluorescent pseudomonads as biocontrol agents and fulfills diverse beneficial interaction in plants leading to promising solution for sustainable and environment friendly agriculture. Thirty-four isolates were showed a broad-spectrum antifungal activity against phytopathogenic fungi, Rhizoctonia solani AG 2-2, Fusarium solani and Pythium arrhenomanes. The phenotypic characterization of twenty isolates confirmed their relation to fluorescent pseudomonads. The gene sequencing of these bacteria revealed that all isolates belonged different species and strains of pseudomonas. The current study indicated that the Pseudomonas strains have ability to colonize the root of bean and more effective in suppressing pathogenic fungi on plants under greenhouse pot experiment as well as promoted the plant growth.

\section{REFERENCES}

Ahmed, F., I. Ahmed and M. S. Khan (2005). Indole acetic acid production by the indigenous isolates of Azotobacter and fluorescent Pseudomonas in the presence and absence of tryptophan. Turk. J. Biol., 29: 29-34.

Asghar, H., Z. Zahir, M. Arshad and A. Khaliq (2002). Relationship between in vitro production of auxins by rhizobacteria and their growth-promoting activities in Brassica juncea L. Biol. Fert. Soils, 35(4): 231-237.

Ayyadurai, N., P. Ravindra Naik, M. Sreehari Rao, R. Sunish Kumar, S. K. Samrat, M. Manohar and N. Sakthivel (2006). Isolation and characterization of a novel banana rhizosphere bacterium as fungal antagonist and microbial adjuvant in micropropagation of banana. J. Appl. Microbiol., 100(5): 926-937.

Bano, N. and J. Musarrat (2004). Characterization of a novel carbofuran degrading Pseudomonas $s p$. with collateral biocontrol and plant growth promoting potential. FEMS Microbiol. Lett., 231(1): 13-17.

Bhattacharyya, P. N. and D. K. Jha (2012). Plant growth-promoting rhizobacteria (PGPR): emergence in agriculture. World J. Microbiol. Biotechnol., 28(4): 1327-1350.

Bloemberg, G. V. and B. J. Lugtenberg (2001). Molecular basis of plant growth promotion and biocontrol by rhizobacteria. Curr. Opin. Plant Biol., 4(4): 343-350.

Brick, J. M., R. M. Bostock and S. E. Silverstone (1991). Rapid in situ assay for indole acetic acid production by bacteria immobilized on a nitrocellulose membrane. Appl. Environ. Microbiol., 57(2): 535-538. 
Cattelan, A. J., P. G. Hartel and J. J. Fuhrmann (1999). Screening for plant growth-promoting rhizobacteria to promote early soybean growth. Soil Sci. Soc. Am. J., 63(6): 1670-1680.

Couteaudier, Y. and C. Alabouvette (1990). Quantitative comparison of Fusarium oxysporum competitiveness in relation to carbon utilization. FEMS Microbiol. Lett., 74(4): 261-267.

Defago, G. E. and D. Haas (1990). Pseudomonads as antagonists of soilborne plant pathogens: modes of action and genetic analysis. Soil Biochem, 6(49): 291.

Dey, R., K. K. Pal, D. M. Bhatt and S. M. Chauhan (2004). Growth promotion and yield enhancement of peanut (Arachis hypogaea L.) by application of plant growth-promoting rhizobacteria. Microbiol. Res., 159(4): 371-394.

Fang, X., D. Phillips, H. Li, K. Sivasithamparam and M. J. Barbetti (2011). Comparisons of virulence of pathogens associated with crown and root diseases of strawberry in Western Australia with special reference to the effect of temperature. Sci. Hortic., 131: 39-48.

Gaind, S. and A. C. Gaur (2002). Impact of fly ash and phosphate solubilising bacteria on soybean productivity. Bioresour. Technol., 85(3): 313-315.

García, J. L., M. Schloter, T. Durkaya, A. Hartmann and F. G. Mañero (2003). Colonization of pepper roots by a plant growth promoting Pseudomonas fluorescens strain. Biol. Fert. Soils, 37(6): 381385.

Gardner, J. M., J. L. Chandler and A. W. Feldman (1984). Growth promotion and inhibition by antibiotic-producing fluorescent pseudomonads on citrus roots. Plant Soil, 77(1): 103-113.

Grunenwald, H. (2000). Direct PCR from a single bacterial colony without DNA extraction using the FailSafe $^{\mathrm{TM}}$ PCR system. Epicentre Forum, 7(6): 12.

Gyaneshwar, P., G. N. Kumar, L. J. Parekh and P. S. Poole (2002). Role of soil microorganisms in improving P nutrition of plants. In: Food Security in Nutrient-Stressed Environments: Exploiting Plants' Genetic Capabilities. pp. 133-143. Springer Netherlands.

Haas, D. and G. Défago (2005). Biological control of soil-borne pathogens by fluorescent pseudomonads. Nat. Rev. Microbiol., 3(4): $307-$ 319.

Jackson, M. L. (1973). Soil chemical Analysis. pp. 150155. Prentice Hall Ind. Pvt. Ltd. Delhi.

Karnwal, A. (2009). Production of indole acetic acid by fluorescent Pseudomonas in the presence of Ltryptophan and rice root exudates. J. Plant Pathol., 61-63.

Keel, S. (1992). Intersection theory of moduli space of stable n-pointed curves of genus zero. T. Am. Math. Soc., 545-574.

Khalid, A., M. Arshad and Z. A. Zahir (2004). Screening plant growth-promoting rhizobacteria for improving growth and yield of wheat. J. Appl. Microbiol., 96(3): 473-480.
Kings, E. O., M. K. Ward and D. E. Raney (1954). Two simple media for the demonstration of pyocyanin and fluorescin. J. Lab. Clin. Med., 44(2): 301-307.

Kpomblekou, A.K. and M. A. Tabatabai (1994). Effect of organic acids on release of $\mathrm{P}$ from phosphate rocks. Soil Sci., 158: 442-443.

Leinhos, V. and O. Vacek (1994). Biosynthesis of auxins by phosphate-solubilizing rhizobacteria from wheat (Triticum aestivum and rye (Secalecereale). Microbiol. Res., 149(1): 31-35.

Lugtenberg, B. J., L. Dekkers and G. V. Bloemberg (2001). Molecular determinants of rhizosphere colonization by Pseudomonas. Annu. Rev. Phytopathol., 39(1): 461-490.

Mac Faddin, J. F. (1980). Biochemical tests for identification of medical bacteria. Williams and Wilkins, Baltimore.

Mafia, R. G., A. C. Alfenas, E. M. Ferreira, D. H. B. Binoti, G. M. V. Mafia and A. H. Mounteer (2009). Root colonization and interaction among growth promoting rhizobacteria isolates and eucalypts species. Revista Árvore, 33(1): 1-9.

Mazzola, M. and Y. H. Gu (2002). Wheat genotypespecific induction of soil suppressiveness to Rhizoctonia solani. Phytopathol., 92.

Moeinzadeh, A., F. Sharif-Zadeh, M. Ahmadzadeh and F. Tajabadi (2010). Biopriming of sunflower (Helianthus annuus L.) seed with Pseudomonas fluorescens for improvement of seed invigoration and seedling growth. Aust. J. Crop Sci., 4(7): 564570.

Nautiyal, C. S., S. Bhadauria, P. Kumar, H. Lal, R. Mondal and D. Verma (2000). Stress induced phosphate solubilization in bacteria isolated from alkaline soils. FEMS Microbiol. Lett., 182: 291296.

Neilands, J. B. (1995). Siderophores: structure and function of microbial iron transport compounds. J. Biol. Chem., 270(45): 26723-26726.

Pandey, A. and L. M. S. Palni (1998). Isolation of Pseudomonas corrugata from Sikkim Himalaya. World J. Microbiol. Biotechnol., 14(3): 411-413.

Patriquin, H., M. Lafortune, P. N. Burns and M. Dauzat, (1987). Duplex Doppler examination in portal hypertension: technique and anatomy. Am. J. Roentgenol., 149(1): 71-76.

Patten, C. L. and B. R. Glick (2002). Regulation of indoleacetic acid production in Pseudomonas putida GR12-2 by tryptophan and the stationaryphase sigma factor RpoS. Can. J. Microbiol., 48(7): 635-642.

Pedraza, R. O., A. Ramírez-Mata, M. L. Xiqui and B. E. Baca (2004). Aromatic amino acid aminotransferase activity and indole-3-acetic acid production by associative nitrogen-fixing bacteria. FEMS Microbiol. Lett., 233(1): 15-21.

Peix, A., R. Rivas, P. F. Mateos, E. Martínez-Molina, C. Rodríguez-Barrueco and E. Velázquez (2003). Pseudomonas rhizosphaerae sp. nov., a novel species that actively solubilizes phosphate in vitro. Int. j. Syst. Evol. Microbiol., 53(6): 2067-2072.

Persello-Cartieaux, F.P., L. Nussaume and C. Robaglia (2003). Tales from the underground: molecular 
plant-rhizobia interactions. Plant Cell Environ., 26: 189-199.

Pikovskaya, R. I. (1948). Mobilization of phosphorus in soil in connection with vital activity of some microbial species. Mikrobiologiya, 17(362): 370.

Rangarajan, S., L. M. Saleena, P. Vasudevan and S. Nair (2003). Biological suppression of rice diseases by Pseudomonas spp. under saline soil conditions. Plant Soil, 251(1): 73-82.

Reddy, B. P., K. R. N. Reddy, M. S. Rao and K. S. Rao, (2008). Efficacy of antimicrobial metabolites of Pseudomonas fluorescens against rice fungal pathogens. Curr. Trends Biotechnol. Pharm., 2(1): 178-182.

Rodriguez, H., T. Gonzalez, I. Goire and Y. Hashan (2004). Gluconic acid production and phosphate solubilization by the plant growth-promoting bacterium Azospirillum spp. Naturwissenschaften, 91: 552-555.

Saber, Fakria, M.A., A. A. Abdelhafez, E. A. Hassan and E. M. Ramadan (2015). Characterization of fluorescent pseudomonads isolates and their efficiency on the growth promotion of tomato plant. Ann. Agric. Sci., 60(1): 131-140.
Sarwar, M., M. Arshad, D. A. Martens and Jr. W. T. Frankenberger (1992). Tryptophan-dependent biosynthesis of auxins in soil. Plant Soil, 147(2): 207-215.

Skidmore, A. M. and C. H. Dickinson (1976). Colony interactions and hyphal interference between Septorianodorum and phylloplane fungi. Trans. Br. Mycol. Soc., 66(1): 57-64.

Toppo, S. R. and P. Tiwari (2015). In vitro antagonistic activity of Pseudomonas spp. against Rhizoctonia soloni. Afr. J. Microbiol. Res., 9(25): 1622-1628.

Van Loon, L. C., P. A. H. M. Bakker and C. M. J. Pieterse (1998). Systemic resistance induced by rhizosphere bacteria. Ann. Rev. Phytopathol., 36(1): 453-483.

Vincent, J. M. (1927). Distortion of fungal hyphae in the presence of certain inhibitors. Nature, 159(4051): 850.

Weller, D. M., J. M. Raaijmakers, B. B. M. Gardener and L. S. Thomashow (2002). Microbial populations responsible for specific soil suppressiveness to plant pathogens. Ann. Rev. Phytopathol., 40(1): 309-348. 